\title{
KEPEMIMPINAN KEPALA \\ MADRASAH DALAM MEWUJUDKAN \\ PEMBELAJARAN EFEKTIF DI \\ MADRASAH IBTIDAIYYAH RAHMAH \\ EL YUNUSIYYAH DINIYYAH PUTERI \\ PADANG PANJANG
}

\author{
en $\infty$ \\ Emi Ratna Aprilana \\ Kementrian Agama Padang Panjang, Sumatera Barat, Indonesia \\ emiratna@gmail.com \\ Muhammad Kristiawan \\ Pascasarjana IAIN Batusangkar, Sumatera Barat, Indonesia

\section{Hafulyon} \\ IAIN Batusangkar, Sumatera Barat, Indonesia \\ oum
}

\begin{abstract}
This study was aimed at describing the headmaster' leadership of Islamic Primary School Rahmah El Yunusiyyah in applying effective learning. The subjects were sectional leader of education, headmaster, teachers, staffs, parents and students. This study applied qualitative case study. The headmaster's leadership of Islamic Primary School Rahmah El Yunusiyyah produced many achievements. The effective learning was done in order to produce students' good attitude and achievement. The headmaster's leadership was seen good, because his caring on developing teachers and students' participation. The headmaster applied 1) technical skills; 2) human skills; and 3) conceptual skills on his leadership. The headmaster suggested the teachers to use Curriculum 2013 and School Based Curriculum by using domain approach. The domain approach tend to grow the project based character building in order to empower students' understanding. The school was also did learning by using environment and earth.
\end{abstract}

Keywords: headmaster' leadership, effective learning, Islamic Primary School Rahmah El Yunusiyyah, Padang Panjang 


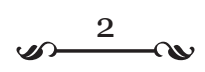

\section{A. Pendahuluan}

Madrasah Ibtidaiyah Rahmah El Yunusiyyah (MI REY) Diniyyah Puteri Padang Panjang adalah salah satu jenjang pendidikan tingkat sekolah dasar yang telah memadukan antara ilmu pengetahuan umum dan ilmu agama guna melahirkan generasi dambaan umat. Sebagai sekolah agama yang dikelola oleh Yayasan Rahmah El Yunusiyyah Perguruan Diniyyah Puteri Padang Panjang, MI REY telah menerapkan sistem pendidikan secara intensif dengan kualitas lulusan yang membanggakan. Cerdas secara akademik, agama dan emosional. Visi MI REY ialah terwujudnya MI terbaik nasional, mampu melahirkan generasi yang sholeh dan sholehah, cerdas, mandiri, berakhlak mulia, ta'at beribadah dekat dengan Al-quran dan sunnah nabi (Studi Dokumentasi Website Perguruan Diniyyah Puteri Padang Panjang).

Penelitian ini berawal dari penuturan Drs. H. Bustami (Kasi Pendidikan Madrasah Kantor Kementerian Agama Kota Padang Panjang) pada wawancara tanggal 18 April 2016 di Kementerian Agama Kota Padang Panjang. Menurut beliau "MI REY Padang Panjang memiliki cara pembelajaran yang unik namun efektif, hal ini tampak dari kunjungan yang dilakukannya, para guru dalam jam istirahat tetap berada di dalam kelas untuk memeriksa hasil belajar peserta didik dan memonitoring perkembangan peserta didik dengan menu snack yang sudah tersedia, ketika pergantian jam pelajaran pun guru kelas tetap duduk di kelas dengan pergantian posisi duduk di belakang peserta didik untuk mengamati penerimaan dan perubahan sikap peserta didik. Jadi tidak ada ruang guru, guru tempatnya di kelas berbaur dengan peserta didik. Selain itu MI REY juga menanamkan nilai karakter atau pendekatan domain yang ranahnya kepada karakter peserta didik, sehingga peserta didik sedini mungkin dibimbing dan diarahkan maka lahirlah generasi yang cerdas dan berakhlak, ini tidak lepas dari peran kepemimpinan kepala madrasah dan seluruh civitas pendidik dan tenaga kependidikan".

Dari pengamatan peneliti, MI Rahmah El Yunusiyyah termasuk madrasah yang memiliki peminat yang tinggi. Sesuai penuturan Mira Lestari tanggal 18 April 2016, tenaga kependidikan di MI REY bahwa tahun 2015 pendaftar sebanyak 141 calon peserta didik yang diterima dan lulus seleksi sebanyak 71 peserta didik. Sedangkan tahun 2016 pendaftar sebanyak 94 yang diterima 49 peserta didik. Hal ini disebabkan kurangnya ruang belajar untuk PBM sementara peminat cukup tinggi.

MI REY memiliki berbagai prestasi yang diraih oleh peserta didik 


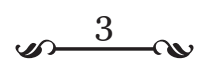

sesuai penuturan Mira Lestari tanggal 18 April 2016 di antaranya tahun 2015 Harapan I Lomba Madrasah Sehat Tk. MI Se-Sumatera Barat, lomba Olimpiade Sains Tahun 2015 Juara I cabang catur atas nama Atika Putri, juara I Lompat Jauh Putri atas nama Tessalia Diara Zaverine Mendrofa. Berdasarkan data yang peneliti peroleh di Kementerian Agama Kota Padang Panjang, adapun prestasi Madrasah Ibtidaiyyah Rahmah El Yunusiyyah (MI REY) di antaranya ajang Kompetisi Seni dan Olahraga Madrasah (AKSIOMA) atas nama M. Ghazi juara II cabang Atletik 6om, Laras Putri juara II, Ririn K juara III cabang atletik 6om putri Tk. MI Se-Kota Padang Panjang. Cabang MTQ Said Aqil juara I, Aditira RF Thamrin juara II dan Majda Syarif juara I MTQ Puteri MI (Studi Dokumentasi SK Kepala Kantor Kementerian Agama Kota Padang Panjang, Nomor. Kd.o3/12-b/PP.oo/766/2015, tanggal 28 Mei 2015).

Untuk Kompetisi Sains Madrasah (KSM) prestasi yang diraih MI REY di antaranya bidang studi Matematika, Tiara Putri Azizah Peringkat I, Aufaniswatul Dase juara II. Bidang studi sains (IPA) Andini Amalia Putri SW Peringkat I, bidang studi Aqidah akhlak Ahda Sabila peringkat I, bidang studi Fiqih Rafidah Azzakirah peringkat I dan bidang studi Alquran hadits Dinda Aliya Fadila Peringkat II (Studi Dokumentasi SK Kepala Kantor Kementerian Agama Kota Padang Panjang, Nomor. Kd.03/12-b/PP.00/767/2015, tanggal 28 Mei 2015). Sedangkan prestasi Kepala Madrasah pada tahun 2015 meraih peringkat I Kepala Madrasah MI Berprestasi Se-Kota Padang Panjang, dan juara II di Tk. Kanwil Kemenag Propinsi Sumatera Barat di Padang (Studi Dokumentasi Kepala Kantor Kementerian Agama Kota Padang Panjang, tanggal 10 Agustus 2015).

Untuk mewujudkan pembelajaran efektif, MI REY berkoordinasi dengan sekolah dasar lainnya, terlihat dari kunjungan Sekolah Insan Cendikia Mandiri Jakarta ke MI REY (Studi Dokumentasi Facebook MI REY, 19 Oktober 2015). MI REY mengadakan training parenting untuk orang tua peserta didik kelas I (Studi Dokumentasi Facebook MI REY, 2 November 2015). Pada tahun 2016, MI REY pada SPEN-FIVE EXPO 2016 yang dilaksanakan di SMP 5 Padang Panjang berhasil meraih juara 2 dalam lomba sains tingkat SD se-Pabasko (Studi Dokumentasi Whats App Guru dan Ortu MI REY, 11 Maret 2016). Pada Kompetisi Sains Madrasah Tingkat Kota Padang Panjang bidang studi Matematika Juara 1 atas nama Shabrina Zakiya Azri, bidang studi IPA atas nama Fathiya Fadilla Akmal Juara 3, 


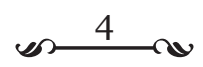

bidang studi Sejarah Kebudayaan Islam juara I atas nama Aqil Mahmuda Rahmat, juara II Ismail Syafril, bidang studi Aqidah Akhlak, Atika Putri juara I, bidang studi Alquran Hadits juara I atas nama Arlini Rahma Dina (Studi Dokumentasi Kepala Kantor Kementerian Agama Kota Padang Panjang Nomor. Kd.o3/12-b/PP.oo/351/2016, tanggal 21 Maret 2016).

MI REY juga memperoleh prestasi dalam seleksi olimpiade sains nasional Tk. SD/MI Se-Kota Padang Panjang Tahun 2016, pada bidang studi IPA juara I atas nama Atika Putri, Fathiya Adila Akmal juara II, Diva Ardelian Putri juara III (Studi Dokumentasi SK Kepala Dinas Pendidikan Kota Padang Panjang, Nomor. 421.1/39/PDD-PP/2016 tanggal 22 Maret 2016). Pada olimpiade PAI di MTsN Paninjauan, Rafidah mewakili MI REY meraih juara II (Studi Dokumentasi Whats App Guru dan Ortu MI REY 2016, 22 Maret 2016). Adapun prestasi yang diperoleh oleh tenaga kependidikan MI REY di antaranya Marlena, M.Pd.I Juara I Kepala Madrasah Berprestasi, Yulidawati, S.Ag juara II dan Nuriah,S.Pd juara III pada lomba guru berprestasi Tk. MI (Studi Dokumentasi SK Kepala Kantor Kementerian Agama Kota Padang Panjang Nomor. Kd.o3/12-b/KP.oo.3/412/2016, tanggal 4 April 2016).

Madrasah Ibtidaiyah Rahmah El Yunusiyyah yang beralamat di jalan Abdul Hamid Hakim Nomor 30 Padang Panjang Provinsi Sumatera Barat, NPSN 10304694 telah terakreditasi dengan nilai 91 dan meraih peringkat A (Amat Baik) (Studi Dokumentasi SK Badan Akreditasi BA P-S/M Nomor. 851/BAP-SM/LL/X/2015, tanggal 16 Oktober 2015 ditetapkan di Padang).

Keberhasilan sebuah lembaga pendidikan ditentukan oleh peran kepemimpinan kepala sekolah dan menurut peneliti hal ini penting untuk diteliti. Kepala sekolah menurut Wahjosumidjo (2005: 83) adalah tenaga fungsional guru yang diberikan tugas tambahan untuk memimpin suatu sekolah di mana diselenggarakan proses belajar mengajar atau tempat di mana terjadi interaksi antara guru yang memberi pelajaran dan murid yang menerima pelajaran. Kepemimpinan kepala sekolah sangat menunjang akan tercapainya pengelolaan sekolah yang efektif dan efisien. Fokus kepemimpinan kepala sekolah menurut Musbikin (2013: 9) adalah perbaikan proses pendidikan dan pembelajaran untuk mencapai pendidikan yang berkualitas.

Mulyasa (2003) mengemukakan bahwa Dinas Pendidikan telah menetapkan bahwa kepala sekolah harus mampu melaksanakan pekerjaan sebagai 1) educator; 2) manager; 3) administrator; 4) supervisor; 5) 


\section{5 ( 5}

leader; 6) innovator; dan 7) motivator. Dalam melaksanakan fungsinya sebagai educator, kepala sekolah harus memiliki strategi yang tepat untuk meningkatkan profesionalisme tenaga pendidikannya di sekolahnya. Salah satu upaya kepala sekolah dalam meningkatkan kinerjanya sebagai educator ialah menggunakan waktu belajar secara efektif di sekolah dengan cara mendorong para guru untuk memulai dan mengakhiri pembelajaran sesuai waktu yang telah ditetapkan serta memanfaatkannya secara efektif dan efisien untuk kepentingan pembelajaran. Lampiran Peraturan Menteri Pendidikan Nasional Nomor 41 Tahun 2007 Tanggal 23 November 2007 tentang Standar Proses untuk Satuan Pendidikan Dasar dan Menengah menjelaskan pembelajaran adalah proses interaksi peserta didik dengan guru dan sumber belajar pada suatu lingkungan belajar. Proses pembelajaran perlu direncanakan, dilaksanakan, dinilai, dan diawasi agar terlaksana secara efektif dan efisien.

Penelitian ini menggunakan pendekatan kualitatif karena berupaya memahami dan mengkaji fenomena atau peristiwa, orang, objek, atau proses yang terkait dengan kepemimpinan kepala madrasah dalam mewujudkan pembelajaran efektif di MI Rahmah El Yunusiyyah Padang Panjang. Sukmadinata (2011) menyatakan "penelitian kualitatif ditujukan untuk memahami fenomena-fenomena sosial dari sudut atau perspektif partisipan. Partisipan adalah orang-orang yang diajak berwawancara, diobservasi, diminta memberikan data, pendapat, pemikiran dan persepsinya”.

Penelitian ini dilakukan melalui penyelidikan dan pengamatan semua objek yang diteliti dengan mengungkapkan semua fakta yang ada pada saat penelitian berlangsung. Jenis penelitian yang digunakan adalah desain studi kasus yang berupaya menelaah sebanyak mungkin data mengenai subjek yang diteliti. Penelitian studi kasus menurut Creswell (2007: 73) adalah " $a$ qualitative research approach in which the investigator explore a bounded system (a case) or multiple bonuded systems (cases) over time through detailed, indepth data collection involving multiple source information. Kemudian menurut Hancock, et.al (2006) studi kasus adalah penelitian yang dilakukan menurut obyek yang disebut sebagai kasus yang dilakukan secara menyeluruh dan mendalam dengan menggunakan berbagai macam sumber data. Sumber data dalam penelitian ini adalah Kepala Madrasah, Kasi Pendidikan Madrasah, Guru, Siswa dan Orang Tua Siswa.

Dalam menggumpulkan data, peneliti menggunakan teknik 


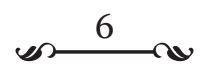

wawancara/interview; dan dokumentasi. Instrumen wawancara menurut Esterberg (2002) adalah "a meeting of two persons to exchange information and idea through question and responses, resulting in communication and joint construction of meaning about a particular topic”. Sugiyono (2012) mengungkapkan bahwa wawancara adalah merupakan pertemuan dua orang untuk bertukar informasi dan ide melalui Tanya jawab, sehingga dapat dikontruksikan makna dalam suatu topik tertentu. Peneliti menggunakan wawancara semi tersruktur (pelaksanaan wawancara lebih bebas, dan bertujuan untuk menemukan permasalahan secara lebih terbuka di mana responden dimintai pendapat dan ide-idenya. Sejalan dengan pendapat Moleong (2002: 135) wawancara memiliki tujuan tertentu, dalam penelitian ini peneliti dan responden berhadapan langsung (tatap muka) untuk mendapatkan informasi secara lisan dengan mendapatkan data tujuan yang menjelaskan masalah penelitian.

Menurut Arikunto (2002) metode dokumentasi adalah "mencari data yang berupa catatan, transkrip, buku, surat kabar, majalah, prasasti, notulen rapat, legger, agenda dan sebagainya”. Nawawi (2005) menyatakan bahwa studi dokumentasi adalah "cara pengumpulan data melalui peninggalan tertulis terutama berupa arsip-arsip dan termasuk juga buku mengenai pendapat, dalil yang berhubungan dengan masalah penyelidikan”. Dalam penelitian ini peneliti menggunakan dokumen-dokumen madrasah yang berhubungan dengan penelitian sebagai bukti dari pelaksanaan penelitian baik.

\section{B. Pembahasan}

\section{Kepemimpinan Kepala Madrasah}

Kepemimpinan merupakan aspek penting dalam menentukan berhasil tidaknya suatu organisasi, karena menyangkut perilaku seorang pemimpin dalam rangka mempengaruhi para pegawai/karyawannya, sehingga para pegawai mau bekerjasama dalam rangka mewujudkan tujuan organisasi. Kepemimpinan berfungsi sebagai tindakan yang dilakukan pemimpin dalam upaya menggerakkan bawahan agar berbuat sesuatu guna menyukseskan program-program kerja yang telah dirumuskan. Menurut Howell, et. al. (1993) kepemimpinan sebagai suatu konsep yang di dalamnya mengandung makna suatu proses kekuatan yang datang dari figur pemimpin untuk mempengaruhi orang lain baik secara individu maupun kelompok dalam 


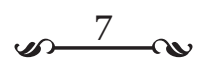

suatu organisasi. Menurut Covey (1997: 26) dalam bukunya "The Principle Centered Leadership" seorang pemimpin yang efektif memiliki prinsipprinsip dalam membangun organisasinya. Prinsip adalah bagian dari kondisi, kesadaran dan suara hati. Prinsip dapat menimbulkan kepercayaan dan merupakan kompas yang menunjukkan arah, panduan yang tidak berubah. Menurut Sujanto (2009: 68) kepemimpinan yaitu perilaku seorang pemimpin untuk mengarahkan, mempengaruhi, dan menjelaskan kepada bawahan, berinisiasi dan memelihara kekompakan kelompok, sikap konsisten agar setiap anggota dapat memberikan sumbangan secara efektif kepada organisasi demi tercapainya tujuan.

Sementara Yulk (1989: 3) menjelaskan bahwa leadership is the process of influencing the activities of an organized group toward goal achievement. Menurut Mutohar (2013: 237-238) beberapa hal yang harus diperhatikan dalam melaksanakan kepemimpinan kepala madrasah agar bisa berhasil dengan baik, di antaranya sebagai berikut.

1. Kemampuan kepala madrasah yang harus dimiliki a) technical skills, dalam hal ini kepala madrasah harus menguasai pengetahuan tentang metode, proses, prosedur serta teknik melakukan kegiatan khusus dan kemampuan untuk memanfaatkan dan mendayagunakan sarana prasarana untuk mendukung kegiatan khusus tersebut; b) human skills, kompetensi ini berkaitan dalam memahami perilaku manusia dalam proses kerja sama, kemampuan dalam memahami isi hati, sikap, dan motif orang lain, kemampuann untuk berkomunikasi secara jelas dan efektif, kemampuan menciptakan kerja sama yang efektif, kooperatif, praktis dan diplomatis, mampu berprilaku yang dapat diterima; c) conceptual skills, kemampuan analisis, berpikir rasional, ahli dan cakap dalam berbagai macam konsepsi, mampu menganalisis berbagai kejadian, mampu mengantisipasi berbagai perintah, mampu mengenali berbagai macam kesempatan dan problemproblem sosial;

2. Mempengaruhi orang lain, sehingga dapat bekerjasama dalam mencapai tujuan yang telah ditetapkan;

3. Kepala Sekolah/Madrasah harus mampu membangun interaksi antar individu dan kelompok dalam organisasi yang baik. Pemimpin dituntut mempunyai kecerdasan emosional sehingga dapat mengenali emosi diri, mengelola emosi, memotivasi diri sendiri, mengenali emosi orang lain, dan mampu membina hubungan yang baik; 


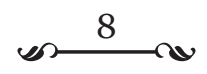

4. Kepala Madrasah harus mampu membangun kerja sama dengan baik pada lingkup internal dan eksternal dalam meningkatkan mutu pendidikan;

5. Tujuan harus dirumuskan dengan jelas dan operasional sesuai dengan visi dan misi Madrasah. Tujuan sebagai tolak ukur untuk keberhasilan Madrasah sesuai dengan harapan dan cita-cita Madrasah yang tertuang dalam visi dan misi Madrasah; dan

6. Program kegiatan yang telah dirumuskan oleh Madrasah, baik kurikuler maupun ekstrakurikuler harus bisa dijalankan secara efektif dan efisien sehingga tujuan bias tercapai dan produktivitas kompetensi dimadrasah bias diwujudkan dengan baik.

Kepala sekolah merupakan salah satu komponen pendidikan yang paling berperan dalam meningkatkan kualitas pendidikan sebagaimana tertuang dalam Pasal 6 Peraturan Menteri Agama RI Nomor 29 Tahun 2014 tentang Kepala Madrasah bahwa "Kepala Madrasah bertanggung jawab atas perencanaan, pelaksanaan, evaluasi pembelajaran dalam rangka pencapaian visi, misi, dan tujuan madrasah, dan pelaksanaan, dan pencapaian standar nasional pendidikan di Madrasah. Pada Pasal 9 tentang kompetensi, Kepala Madrasah wajib memiliki kompetensi kepribadian, manajerial, kewirausahaan, supervisi dan sosial. Kepala Madrasah dapat dikatakan berprestasi kepemimpinannya apabila memiliki sifat-sifat Intelegence (kecerdasan), Supervisory ability (kemampuan mengawasi), Inisiative (inisiatif), self assurance (Perlindungan diri atau ketegangan) dan individuality (kepribadian) (Sutarto, 1998: 39). Salah satu faktor penentu keberhasilan pemimpin tergantung pada faktor pendekatan terhadap karyawan yang dipimpinnya. Kepemimpinan memiliki dua aspek yang penting yaitu kelebihan individual tehnik kepemimpinan dan keunggulan pribadi dalam hal ketegasan, keuletan, kesadaran, dan keberhasilan (Siswanto 2006: 154). Seseorang yang memiliki kondisi fisik yang baik, memiliki keterampilan yang tinggi, menguasai teknologi, memiliki ikatan yang baik serta imajinasi yang baik, serta imajinasi yang meyakinkan akan mampu memimpin bawahan.

Menurut Koswara (2008) pengembangan kepemimpinan sekolah berkualitas, ada delapan karakter dasar bagaimana effective school leader dapat tumbuh dan berkembang, diantaranya seorang Kepala Sekolah harus menyadari pentingnya menjaga visi dan misi sekolah yang dirumuskan secara bersama. Kedua, kemampuan mengembangkan kemampuan partisipatif guru 


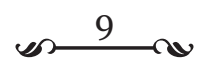

dan siswa. Ketiga, kepedulian Kepala Sekolah terhadap proses pengajaran. Keempat, kemampuan Kepala Sekolah mengelola sumber informasi pembelajaran. Kelima, kebijakan yang transparan dan terbuka dalam proses seleksi guru dan tenaga administratif sekolah. Keenam, orientasi akademis, fokus terhadap pentingnya proses dan capaian dalam bidang akademis juga memiliki korelasi yang signifikan terhadap kepemimpinan. Aspek karakter ketujuh, pentingnya menumbuhkan rasa percaya diri dan kebanggaan komunitas sekolah terhadap sekolahnya. Kedelapan, sistem pemantauan dan evaluasi yang dipilih dan yang akan digunakan sekolah dalam rangka mengukur tingkat kemajuan siswa, guru, orang tua, peserta didik dan manajemen sekolah.

Secara umum, Kepala Sekolah perlu memiliki kemampuan yang menunjang perannya dalam pengambilan keputusan, mencakup kemampuan akal yang cerdas, jiwa yang mantap, dan jasmani yang kuat. Menurut Koswara (2008) beberapa kemampuan penting yang harus dimiliki kepala sekolah di antaranya memahami dan bisa melaksanakan metode serta teknik pengambilan keputusan yang efektif dan efisien sesuai potensi, waktu, kondisi dan situasi yang ada. Memiliki strategi dalam hal pengambilan keputusan yang jelas, efektif dan efisien. Mampu bekerjasama, berpartisipasi, berkolaborasi, dalam sebuah kesatuan teamwork dengan stakeholder sekolah sesuai kebutuhan dan tugas serta wewenang dalam pengambilan keputusan bersama. Bersikap jujur dan adil terhadap setiap situasi dan keadaan. Memiliki profesionalitas dalam hal kepemimpinan pendidikan dan pengambilan keputusan. Mampu mengelola setiap potensi pendapat, keahlian dan kemampuan lainnya. Memiliki deskripsi konsep mutu meliputi input, proses dan ouput.

Dari beberapa pendapat di atas, dapat memberikan kesimpulan bahwa tugas dan fungsi kepemimpinan merupakan proses atau rangkaian mengikuti secara sistematis dengan tingkah laku bawahan dengan pimpinannya yaitu kegiatan penggerakan, membimbing secara perorangan maupun bersama-sama. Seluruh kegiatan tersebut dapat dikatakan sebagai usaha mempengaruhi perasaan, pikiran dan tingkah laku orang lain ke arah pencapaian suatu tujuan. Oleh karena itu, technical skill, human skill dan social skill mewakili seluruh konsep tugas, kewajiban dan fungsi pemimpin yang mengambarkan proses interaksi komunikasi dengan petunjuk yang jelas antar seorang (pemimpin) dengan kelompok yang menyebabkan seseorang 


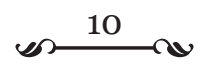

itu dapat berbuat sesuatu dengan kehendak pemimpin untuk mencapai tujuan.

\section{Pembelajaran Efektif}

Pembelajaran ialah membelajarkan siswa menggunakan asas pendidikan maupun teori belajar, yang merupakan penentu utama keberhasilan pendidikan (Sagala, 2006: 61). Landasan pembelajaran dikondisikan agar mampu mendorong kreativitas anak secara keseluruhan, membuat siswa aktif, mencapai tujuan secara efektif dan berlangsung dalam kondisi menyenangkan. Oleh sebab itu setiap pengajar harus berkeyakinan bahwa (Munandar, 1999: 111-112) 1) belajar adalah sangat penting dan sangat menyenangkan; 2) anak patut dihargai dan disayangi sebagai pribadi yang unik; 3) anak hendaknya jadi pelajar yang aktif. Mereka perlu didorong untuk membawa pengalaman, gagasan, minat dan bahan mereka di kelas. Mereka dimungkinkan untuk membicarakan bersama guru tujuan belajar setiap hari, dan perlu diberi otonomi dalam menentukan bagaimana tercapainya pembelajaran tersebut; 4) anak perlu merasa nyaman di kelas, dan dirangsang untuk selalu belajar. Hendaknya tidak ada tekanan dan ketegangan; 5) anak harus mempunyai rasa memiliki dan kebanggaan di dalam kelas; 6) guru merupakan narasumber, fasilitator dan mediator; 7) guru memang harus kompeten, tetapi tidak perlu sempurna; 8) anak perlu merasa bebas untuk mendiskusikan masalah secara terbuka baik dengan guru maupun teman sebaya; 9) kerja sama bernilai lebih daripada kompetisi, walau pada akhirnya mereka harus bertanggung jawab secara pribadi; dan 10) pengalaman belajar (learning experiences) hendaknya dekat dan berasal dari pengalaman yang diperoleh dari dunia nyata (real world).

Pembelajaran efektif dan produktif adalah kegiatan pembelajaran yang secara terencana membantu siswa mencapai dua tujuan utama yaitu mencapai tujuan pembelajaran secara optimal dan sekaligus mengondisikan siswa produktif dalam menghasilkan gagasan-gagasan. Pencapaian tujuan pembelajaran secara optimal merujuk kepada suatu keadaan yang ditandai oleh tercapainya secara maksimal indikator-indikator pembelajaran (Suyono, 2009). Pembelajaran efektif hanya mungkin terjadi jika didukung oleh guru yang efektif. Pakar Pendidikan Gilbert H. Hunt dalam bukunya Effective Teaching, menyebutkan ada tujuh kriteria yang harus dimiliki oleh seorang guru agar tercapai pembelajaran efektif, yaitu (Rosyada, 2004: 


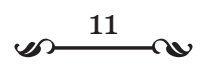

113) 1) guru harus memiliki sifat antusias, memberi ransangan, mendorong siswa untuk maju; 2) guru memiliki pengetahuan yang memadai dalam mata pelajaran yang diampunya, dan terus menerus mengikuti perkembangan dalam bidang ilmunya; 3) guru mampu memberikan jaminan bahwa materi yang disampaikan mencakup semua unit bahasan, semua kompetensi dasar yang diharapkan siswa secara maksimal; 4) guru mampu menjelaskan berbagai informasi secara jelas dan terang; 5) guru mampu memberikan harapan kepada siswa, mampu membuat siswa akuntabel, dan mendorong partisipasi orang tua dalam memajukan kemampuan akademik siswanya; 6) guru mau dan mampu menerima berbagai masukan, risiko, tantangan, selalu memberikan dukungan kepada siswanya; dan 7) guru mampu menunjukkan keahlian dalam perencanaan, pengorganisasian, pengontrolan dan evaluasi.

Adapun indikator pembelajaran yang efektif, menurut Mitchell, et. al. (1993) sebagai berikut 1) perhatian siswa yang aktif dan terfokus kepada pembelajaran; 2) berupaya menyelesaikan tugas dengan benar; 3) siswa mampu menjelaskan hasil belajarnya; 4) siswa difasilitasi untuk berani menyatakan kepada guru, apa yang belum dipahami; 5) siswa berani menyatakan ketidaksetujuan; 6) siswa dimotivasi untuk meminta informasi yang relevan dengan topic bahasan lebih lanjut; 7) siswa didorong untuk terbiasa mencari alasan mengapa hasil kerja salah; 8) dalam mencoba menyelesaikan masalah siswa dibiasakan mengambil sebagai contoh pengalaman pribadi atau kehidupan nyata; 9) siswa dimotivasi; 10) siswa dibiasakan bertanya dengan pertanyaan yang mencerminkan keingintahuan; 11) setelah selesai melaksanakan tugas, siswa terbiasa melakukan cek terhadap hasil kerja; 12) Bila menghadapi jalan buntu, siswa difasilitasi untuk mengacu kepada hasil kerja terdahulu sebelum meminta bantuan kepada orang lain; 13) doronglah siswa agar mampu berinisiatif mewujudkan sejumlah kegiatan yang relevan; dan 14) fasilitasi siswa agar menjadi pribadi yang tabah, tahan uji, tangguh dan tidak mudah menyerah, mampu bekerjasama, tawarkan gagasan alternative kepada siswa, pertimbangkan semua gagasan, lihat kemungkinan alternative pemecahan masalah, dan kemungkinan untuk memperluas pemahaman.

Pembelajaran efektif adalah pembelajaran dimana siswa memperoleh keterampilan-keterampilan yang spesifik, pengetahuan dan sikap serta merupakan pembelajaran yang disenangi siswa. Intinya bahwa pembelajaran dikatakan efektif apabila terjadi perubahan-perubahan pada aspek kognitif, 


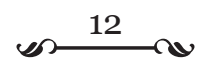

afektif, dan psikomotor (Robert, et. al. 1996).

Pembelajaran efektif diuraikan oleh Depdiknas (2003) dengan jelas yaitu 1) bagaimana mengaktifkan siswa; 2) bagaimana siswa membangun peta konsep; 3) bagaimana mengumpulkan informasi dengan stimulus pertanyaan efektif; 4) bagaimana menggali informasi dari media cetak; 5) bagaimana membandingkan dan mensintesikan informasi; 6) bagaimana mengamati kerja siswa secara aktif; 7) bagaimana cara menganalisis dengan peta akibat atau roda masa depan; serta 8) bagaimana melakukan kerja praktik.

Efektif itu artinya mencapai target yang ditetapkan dalam rencana. Oleh karena itu perencanaan pembelajaran yang efektif adalah yang menetapkan kriteria target dan guru melakukan pengukuran pencapaian. Jadi, mengajar yang efektif itu jika pelaksanaannya terdapat instrumen untuk mengukur keberhasilan dan melaksanakan pengukuran. Pembelajaran yang efektif dapat juga dilihat dari segi proses dan hasil. Dari segi proses, pembelajaran dianggap efektif jika siswa terlibat secara aktif melaksanakan tahapantahapan prosedur pembelajaran. Dari segi hasil, dianggap efektif jika tujuan pembelajaran dikuasai siswa secara tuntas. Bentuk perubahan dari hasil belajar meliputi tiga aspek, yaitu aspek kognitif meliputi perubahanperubahan dalam segi penguasaan pengetahuan dan perkembangan keterampilan atau kemampuan yang diperlukan untuk menggunakan pengetahuan tersebut. Kedua, aspek efektif meliputi perubahan-perubahan dalam segi sikap mental, perasaan dan kesadaran. Ketiga, aspek psikomotor meliputi perubahan-perubahan dalam segi bentuk-bentuk tindakan motorik.

McKenzie (2007) mengidentifikasikan tiga dimensi pendidikan efektif yaitu kepemimpinan, keefektifan dan efisiensi serta unsur pokok dan penunjang masing-masing dimensi tersebut. Sementara Edmonds (1979) menyebutkan bahwa ada lima karakteristik sekolah/madrasah efektif yaitu 1) kepemimpinan dan perhatian Kepala Sekolah/Madrasah terhadap kualitas pengajaran; 2) pemahaman yang mendalam terhadap pengajaran; 3) iklim yang nyaman dan tertib bagi berlangsungnya pengajaran dan pembelajaran; 4) harapan bahwa semua siswa minimal akan menguasai ilmu pengetahuan tertentu; dan 5) penilaian siswa yang didasarkan pada hasil pengukuran hasil belajar siswa.

Proses pembelajaran yang merupakan esensi dari pendidikan diharapkan dapat memenuhi tuntutan dan kebutuhan masyarakat. 


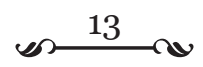

Pendidikan harus dapat memberdayakan semua unsur pendidikan (pemerintah, orang tua, dan masyarakat) agar siswa dapat mengembangkan potensinya, sehingga dapat mencapai efektivitas yang optimal baik di bidang akademik maupun non akademik. Produk pendidikan tergantung dari input maupun proses pendidikan. Salah satu input dari unsur pendidikan adalah siswa. Siswa merupakan suatu komponen masukan dalam sistem pendidikan yang memiliki berbagai potensi seperti bakat, minat maupun kemampuan yang selanjutnya diproses dalam sistem pendidikan, dan diharapkan menjadi manusia yang berkualitas. Manusia yang berkualitas dapat berkembang secara menyeluruh menjadi manusia seutuhnya dalam dimensi kemanusiaan, baik dimensi individualitas, sosialitas, kesusilaan, maupun keberagaman sesuai dengan tujuan pendidikan nasional. Dalam proses pembelajaran juga dibutuhkan tenaga pendidik yang memiliki kemampuan profesional sehingga mampu memberi kemudahan-kemudahan bagi siswa untuk melakukan kegiatan belajar, membantu siswa mengatasi kesulitan, dapat menciptakan lingkungan yang menantang siswa, memberi contoh perlakuan yang baik, membina moral siswa, mampu melakukan penilaian terhadap kemajuan belajar siswa yang muaranya adalah peningkatan efektivitas madrasah (Nurkholis, 2009). Dari beberapa uraian tersebut dapat disimpulkan bahwa pembelajaran efektif adalah cara pandang, pola berpikir, dan sikap kepala madrasah, guru dalam melakukan pembelajaran terhadap peserta didik dengan menggunakan atau memilih metode pembelajaran yang menciptakan pembelajaran efektif untuk mencapai tujuan pembelajaran.

Berdasarkan hasil wawancara dengan Kasi Pendidikan Madrasah, Kepala Madrasah, Pendidik dan Tenaga Kependidikan, Orang tua Siswa, diperoleh informasi berbagai prestasi siswa MI REY. Berdasarkan penuturan Drs. Bustami Kasi Pendidikan Madrasah Kantor Kementerian Agama Kota Padang Panjang "kepemimpinan Kepala Madrasah MI REY dinilai baik, karena kepedulian kepala madrasah dalam mengembangkan kemampuan partisipatif guru dan siswa”. Peranan Kepala Madrasah sebagai manajer sekaligus fasilitator tampak pada sosok kepemimpinan kepala MI REY Padang Panjang. Salah satu kepedulian Kepala Madrasah terhadap proses pengajaran adalah Kepala Madrasah secara rutin berkunjung ke kelas-kelas, memantau sekaligus membimbing guru dan para siswa untuk terlibat aktif dalam pembelajaran. Menjadi partner dalam sebuah proses pembelajaran kolaborasi adalah bukti lain dari sifat dan karakter Kepala Madrasah yang peduli pada proses belajar mengajar terjadi di kelas (Koswara, 2008: 36). 


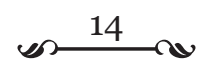

Berdasarkan wawancara tanggal 4 April 2016 dengan beberapa guru, menuturkan bahwa Kepala Madrasah merupakan sosok yang suka memotivasi pendidik dan tenaga kependidikan "kadangkala ada guru yang mulai pesimis dengan programnya, sebagai kepala madrasah beliau menyakinkan kalau kita bisa jika bekerjasama”. Karakter kepemimpinan ini menumbuhkan rasa kepercayaan dan kebanggaan komunitas terhadap sekolahnya. Untuk mewujudkan efektivitas madrasah yang tinggi tidak mungkin dapat diraih tanpa usaha dan kerja sama dari berbagai pihak. Kepala Madrasah sebagai pucuk pimpinan di madrasah mempunyai peran yang sangat strategis menggerakkan dan mengarahkan para guru dalam upaya mewujudkan pembelajaran efektif guna mewujudkan Madrasah yang berkualitas dan meningkatkan mutu pendidikan secara umum. Tetapi bagaimana kemampuan Kepala Madrasah dalam mengelola institusinya yang ditunjukkan seringkali dipersepsikan berbeda-beda oleh para guru yang berakibat pada perbedaan motivasi kerja mereka, tetapi kepala MI REY mampu menumbuhkan motivasi guru (Hasil Observasi, 4 April 2016).

Kepala MI REY telah menerapkan 1) technical skills, dalam hal ini Kepala Madrasah harus menguasai pengetahuan tentang metode, proses, prosedur serta teknik melakukan kegiatan khusus dan kemampuan untuk memanfaatkan dan mendayagunakan sarana prasarana untuk mendukung kegiatan khusus tersebut, sesuai penuturan para guru tanggal 4 April 2016 "Kepala Madrasah berusaha memenuhi sarana prasarana untuk kelancaran pembelajaran”; 2) human skills, kompetensi ini berkaitan dalam memahami perilaku manusia dalam proses kerja sama, kemampuan dalam memahami isi hati, sikap, dan motif orang lain, kemampuann untuk berkomunikasi secara jelas dan efektif, kemampuan menciptakan kerja sama yang efektif, kooperatif, praktis dan diplomatis, mampu berprilaku yang dapat diterima, sesuai dengan penuturan para guru tanggal 4 April 2016 "bahasa komunikasi yang digunakan Kepala Madrasah sudah baik, menerima masukan dari pendidik dan tenaga kependidikan, rapat dan evaluasi dilaksanakan 1 x seminggu setiap Sabtu"; 3) conceptual skills, kemampuan analisis, berpikir rasional, ahli dan cakap dalam berbagai macam konsepsi, mampu menganalisis berbagai kejadian, mampu mengantisipasi berbagai perintah, mampu mengenali berbagai macam kekesempatan dan problem-problem sosial. Berdasarkan penuturan orang tua siswa tanggal 6 April 2016 "melalui WA Guru dan Orang Tua Siswa MI REY mampu menjadi media komunikasi 


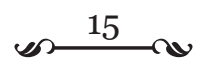

dan informatif antara sekolah dengan orang tua siswa”. Kepala Madrasah mampu menganalis kebutuhan informasi dan perkembangan peserta didik selain melalui buku penghubung juga melalui media sosial. Sesuai penuturan Prof. Dr. Agus Irianto (Minggu, 24 April 2016) di IAIN Batusangkar "bahwa informasi dan komunikasi harus dibina antara keluarga di rumah dengan lingkungan sekolah untuk mengetahui perkembangan peserta didik”.

Menurut Marlena selaku Kepala MI REY (tanggal 4 April 2016) "pembelajaran efektif ialah kalau guru sudah menerapkan pembelajaran sesuai lesson plan yang dibuatnya”. Dalam pembelajaran efektif MI REY menerapkan Kurikulum 2013 dan KTSP dengan Pendekatan Domain. Pendekatan domain menitikberatkan pada penanaman nilai karakter siswa. Adapun program unggulan MI REY tahun ini adalah pembelajaran efektif berbasis proyek, yang bertujuan untuk menguatkan pemahaman peserta didik dengan materi yang diberikan. Selain itu pembelajaran dengan lingkungan dan alam juga dilaksanakan. Berdasarkan penuturan siswa (tanggal 4 April 2016) "pembelajaran di alam, mampu membuat kita paham budaya antri, melihat proses abrasi, kerjasama kelompok". Sesuai penuturan salah satu guru (tanggal 4 April 2016) "pembelajaran alam merupakan salah satu metode pembelajaran efektif karena selama ini peserta didik hanya mengenal lewat TV atau buku, di alam mereka kenal langsung dengan objek pembelajaran”.

Dalam proses pembelajaran yang efektif dibutuhkan profesionalisme guru dalam mengelola pembelajaran sebagai tujuan akhir Efektivitas sekolah. Proses pembelajaran terkait dengan masukan kasar (raw input), pengaruh lingkungan (seperti lingkungan madrasah itu berada, stakeholder, dan pusat keramaian), pengaruh instrumen pendidikan (seperti kurikulum, laboratorium, sarana, dan prasarana) sehingga keluarannya akan mencapai hasil yang maksimal (Nurkholis, 2007). Guru MI REY memiliki sifat antusias, memberi ransangan, mendorong siswa untuk maju. Pada WA Guru dan Orang Tua Siswa, para guru nampak memotivasi dan mendorong siswa dalam membuat jaring-jaring balok dan percobaan miniature gunung meletus. Guru memiliki pengetahuan dalam mata pelajaran yang diampunya, dan terus menerus mengikuti perkembangan dalam bidang ilmunya. Apa yang disampaikan, mampu memberikan jaminan bahwa materi yang disampaikan mencakup semua unit bahasan, semua kompetensi dasar yang diharapkan siswa secara maksimal. Melalui beberapa simulasi, tampak guru mampu menjelaskan berbagai informasi secara jelas dan terang. Para guru mampu 


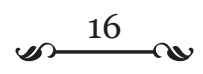

menggali potensi dan keaktifan siswa, dan mendorong partisipasi orang tua dalam memajukan kemampuan akademik siswanya. Reaksi guru terhadap siswa, mau dan mampu menerima berbagai masukan, risiko, tantangan, selalu memberikan dukungan kepada Madrasah.

Pembelajaran efektif di MI REY berdasarkan hasil wawancara 4 April 2016 antara lain guru dapat membantu siswa dalam meningkatkan kemampuan yang diharapkan sesuai dengan tujuan intruksional yang ingin dicapai, terlihat pada prestasi yang diraih peserta didik. Untuk meningkatkan cara belajar yang efektif perlu diperhatikan beberapa hal yaitu pertama, perlunya bimbingan hasil belajar dipengaruhi oleh beberapa faktor seperti kecakapan dan ketangkasan belajar pada setiap individu. Walau demikian, ada beberapa petunjuk umum tentang cara-cara belajar yang efektif, yakni memberi petunjuk saat mereka belajar dan mengawasi, membimbing sewaktu belajar ini dilaksanakan oleh para guru MI REY sesuai dengan penuturan Kasi Pendidikan Madrasah yang peneliti wawancarai (Hasil Wawancara 4 April 2016), "para guru di jam istirahat dan pertukaran jam guru kelas tetap memperhatikan perkembangan peserta didik”. Kedua, kondisi strategi belajar pada MI REY sudah terpenuhi 1) kondisi internal yaitu kondisi yang ada pada diri siswa itu sendiri, misalnya kesehatan, keamanannya, ketentramannya, dan sebagainya; 2) kondisi eksternal yaitu kondisi yang di luar pribadi manusia, umpamanya kebersihan rumah, penerangan serta keadaan lingkungan fisik yang lain. Untuk dapat belajar dengan efektif diperlukan lingkungan fisik yang baik dan teratur, misalnya ruang belajar harus bersih, sirkulasi udara, ruangan cukup tenang, tidak gelap dan tidak mengganggu mata, sarana yang diperlukan dalam belajar yang cukup atau lengkap. Ketiga, metode belajar yaitu cara atau jalan yang harus dilalui untuk mencapai suatu tujuan tertentu, sehingga membutuhkan metode yang tepat dalam belajar. Pada MI REY, metode jurnal adalah salah satu model pengulangan pembelajaran oleh peserta didik di rumah. Cara yang dipakai akan menjadi kebiasaan, dan kebiasaan akan mempengaruhi belajar itu sendiri (Hasil Observasi, 5 April 2016).

Adapun penelitian yang mendukung hasil penelitian ini terkait pembelajaran efektif salah satunya adalah penelitian Hidayat (2008) yang mengungkapkan bahwa efektifitas strategi pembelajaran dan motivasi belajar berpengaruh signifikan terhadap hasil belajar IPA di SD Pandeglang. Kedua, temuan Sari (2013) tentang kontribusi gaya kepemimpinan kepala 


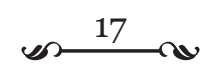

sekolah dan motivasi berprestasi guru terhadap mutu pendidikan di gugus rama 2 UPT Disdikpora Kecamatan Kembang Kabupaten Jepara. Hasilnya menunjukkan terdapat kontribusi gaya kepemimpinan kepala sekolah terhadap mutu pendidikan dengan memberikan sumbangan yang efektif yaitu $18,2 \%$. Kemudian terdapat kontribusi pemberian motivasi berprestasi terhadap mutu pendidikan dengan memberikan sumbangan yang efektif sebesar 30,3\%. Selanjutnya terdapat kontribusi gaya kepemimpinan kepala sekolah dan motivasi berprestasi terhadap mutu pendidikan dengan memberikan sumbangan yang efektif sebesar 32,2\%. Ketiga, temuan Barret dan Breyyer (2014) yang menyimpulkan bahwa administrators must instill passion in teachers and provide effective leadership to motivate teachers to engage and energize students. The primary focus of this study was to determine how modeling instructional strategies by principals influence teachers' implementation of strategies that promote greater student engagement and learning.

Keempat, temuan Suyono (2009) yang mengungkapkan bahwa pengembangan pembelajaran efektif dan produktif memungkinkan pembelajaran yang dirancang guru dapat mendorong siswa banyak belajar memahami dan memecahkan setiap masalah yang ditemuinya secara empirik. Kelima, temuan Panigrahi (2014) yeng menyimpulkan bahwa better teachers profile, healthy student-teacher interaction and effective teaching and evaluation process are the parameters for effective learning which lead to higher school effectiveness. Keenam, penelitian Kusmintardjo (2014) hasil penelitiannya menyimpulkan bahwa sebagai kepemimpinan pembelajaran, kepala sekolah diharapkan mampu mengekspresikan perilaku-perilaku kepemimpinan pembelajaran yang dicirikan dengan peranan dan fungsinya sebagai management engineer, communicator, clinical practioner, role model dan sebagai high priest. Kemudian sebagai pemimpin pembelajaran, kepala sekolah harus mempertimbangkan faktor eksternal dalam upayanya meningkatkan pembelajaran, yakni faktor nilainilai dan harapan masyarakat, dan faktor struktur kelembagaan sekolah. Ketiga, sebagai pemimpin pembelajaran, ada empat dimensi internal sekolah yang perlu dipertimbangkan kepala sekolah dalam meningkatkan kinerja yakni sosialisasi visi dan misi sekolah, penataan pembelajaran, peningkatan praktek pembelajaran dan penciptaan iklim belajar yang sehat.

Ketujuh, penelitian Parsons dan Beauchamp (2012) hasil penelitiannya 


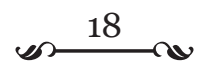

menyimpulkan bahwa principals' influence is often indirect, works through others, and happens best by developing teachers' efficacy in curriculum and instruction, engaging and motivating staff, fostering a shared purpose, creating conditions for effective teaching and learning, fostering program coherence, encouraging organizational learning, and through feedback, direction, and communication. Significant leadership practices include communicating a clear vision and priorities, focusing time and attention on what matters most, enabling teachers to develop pedagogical and content skills and capacity, providing instructional guidance, empowering others to make significant decisions, addressing supportive structures and resources, developing school improvement plans, providing instructional guidance and coherence, engaging the larger school and district community, acting ethically, and engaging in continuous learning and growth.

Kedelapan, penelitian Chang (2012) menyebutkan bahwa principals' technological leadership improves teachers' technological literacy and directly encourages teachers to integrate technology into their teaching. Furthermore, teachers' technological literacy directly affects their effectiveness. Principals' technological leadership also makes teachers more effective. Principals' technological leadership, as mediated by teachers' technological literacy, can affect teaching effectiveness.

Kesembilan, penelitian Dunlosky (2016) dalam jurnal Improving Students' Learning With Effective Learning Techniques: Promising Directions from Cognitive and Educational Psychology menyimpulkan bahwa many students are being left behind by an educational system that some people believe is in crisis. Improving educational outcomes will require efforts on many fronts, but a central premise of this monograph is that one part of a solution involves helping students to better regulate their learning through the use of effective learning techniques. Fortunately, cognitive and educational psychologists have been developing and evaluating easy-to-use learning techniques that could help students achieve their learning goals.

\section{Simpulan}

Madrasah Diniyah Rahmah El Yunusiyyah di bawah kepemimpinan Kepala Madrasah telah melaksanakan pembelajaran efektif. Kepemimpinan Kepala Madrasah telah menghasilkan prestasi-prestasi gemilang. Pembelajaran efektif dilaksanakan dengan menghasilkan peserta didik yang 


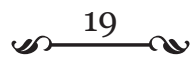

berakhlak mulia dan berprestasi. Sesuai dengan visi MI REYialah terwujudnya MI terbaik nasional, mampu melahirkan generasi yang sholeh dan sholehah, cerdas, mandiri, berakhlak mulia, ta'at beribadah dekat dengan Al-quran dan sunnah nabi.

Kepemimpinan Kepala MI REY dinilai baik, karena kepedulian Kepala MI REY dalam mengembangkan kemampuan partisipatif guru dan siswa. Kepala MI REY berusaha memenuhi sarana prasarana untuk kelancaran pembelajaran. Kepala MI REY telah menerapkan 1) technical skills; 2) human skills; dan 3) conceptual skills. Kepala MI REY mengharuskan guru menggunakan Kurikulum 2013 dan KTSP dengan Pendekatan Domain. Pendekatan domain menitikberatkan pada penanaman nilai karakter siswa program unggulan pembelajaran efektif berbasis proyek, yang bertujuan untuk menguatkan pemahaman peserta didik dengan materi yang diberikan. Selain itu MI REY melaksanakan pembelajaran dengan lingkungan dan alam. 


\subsection{0 \\ DAFTAR PUSTAKA}

Arikunto, S. 2002. Prosedur Penelitian, Suatu Pendekatan Praktek. Jakarta: PT Rineka Cipta.

Barrett, Catherine and Breyer, Robert. 2014. "The Influence of Effective Leadership on Teaching and Learning”. Journal of Research Initiatives: Vol. 1: Iss. 2, Article 3.

Chang, I. H. 2012. "The Effect of Principals' Technological Leadership on Teachers' Technological Literacy and Teaching Effectiveness in Taiwanese Elementary Schools". Educational Technology \& Society, 15 (2), 328-340. Department of Education, National Chengchi University.

Covey, S. R. 1997. The 7 Habits of Highly Effective People. Jakarta: Gramedia. Creswell, J. 2007. Qualitative Inquiry \& Research Design: Choosing Among Five Approaches, 2nd ed. California: Sage Publication.

Depdiknas. 2003. Kegiatan Belajar Mengajar yang Efektif. Jakarta: Pusat Kurikulum, Depdiknas.

Dunlosky, John. 2016. “Improving Students' Learning with Effective Learning Techniques: Promising Directions from Cognitive and Educational Psychology”. SAGE: Kent State University, Kent.

Edmonds, R. R. 1979. "Effective School for the Urban Poor". Educational Leadership Journal Vol. 1. No. 1, 1979.

Hancock, Dawnson. R and Algozzine, Bob. 2006. Doing Case Study Research. New York: Teachers College Press.

Hidayat, Sholeh. 2008. Efektifitas Strategi Pembelajaran dan Motivasi Belajar terhadap Hasil Belajar IPA. e-Jurnal.com

Howell, J. M. and Avolio, B.J. 1993. "Transformational Leadership, Transactional Leadership, Locus of Control, and Support for Innovation: Key Predictors of Consolidated-Business-Unit Performance”. Journal of Applied Psychology, 78 (6): 680-694

Koswara, Deni D. 2008. Sembilan Kebiasaan Kepala Sekolah Efektif. Bandung: PT Pribumi Mekar.

Kusmintardjo. 2014. Kepemimpinan Pembelajaran oleh Kepala Sekolah. Malang: Universitas Negeri Malang. 


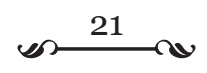

McKenzie, Amy R. 2007. "The Use of Learning Media Assessments with Students Who Are Deaf-Blind”. AFB, All Rights Reserved Journal of Visual Impairment \& Blindness

Mitchell, S. \& Albanese. 1993. "Problem-based Learning: a Review of Literature on its Outcomes and Implementation Issues”. Academic Medicine, 68(1), pp. 52-81.

Moleong, Lexy. 2002. Metodologi Penelitian Kualitatif. Bandung: PT. Remaja Rosdakarya

Mulyasa, E. 2003. Manajemen Berbasis Madrasah, Konsep Strategi dan Implementasi. Bandung: Rosdakarya.

Munandar, Utami. 1999. Pengembangan Kreativitas Anak Berbakat. Jakarta: Rineka Cipta.

Musbikin, Imam. 2013. Menjadi Kepala Sekolah yang Hebat. Pekanbaru: Zanafa Publishing.

Mutohar, Prim Masrokan. 2013. "Gaya Kepemimpinan Kepala Sekolah, Budaya Organisasi dan Iklim Organisasi Dengan Motivasi Berprestasi Guru”. Jurnal Kajian Teori dan Praktek Kependidikan FIP Universitas Malang. Vol.21 no. 1 (24O-246).

Nawawi, Hadari. 2005. Metode Penelitian Bidang Sosial. Yogyakarta: Gadjah Mada University Press.

Nurkholis, M. 2007. Korelasi Antara Kemampuan Manajerial Kepala Madrasah Dan Iklim Madrasah dengan Efektivitas Madrasah Aliyah Negeri di Kabupaten Brebes. Universitas Negeri Semarang: Tesis.

Panigrahi, Manas Ranja. 2014. School Effectiveness at Primary Level of Education in Relation to Classroom Teaching. Ethiopia: Haramaya University.

Parsons, Jim. \& Beauchamp, Larry. 2012. Leadership in Effective Elementary Schools: A Synthesis of Five Case Studies. Canada: University of Alberta.

Peraturan Menteri Agama RI Nomor 29 Tahun 2014

Permendiknas No 41 Tahun 2007 tentang Standar Proses Untuk Satuan Pendidikan Dasar dan Menengah

Robert, Reiser \& Dick, W. 1996. Instructional planning, a guide for teachers. Boston: Allyn and Bacon 


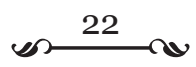

Rosyada, Dede. 2004. Paradigma Pendidikan Demokratis. Jakarta: Primada Media.

Sagala, Saiful. 2006. Konsep dan Makna Pembelajaran. Bandung: CV. Alfabeta

Sari, Dewi Puspita. 2013. Kontribusi Gaya Kepemimpinan Kepala Sekolah dan Motivasi Berprestasi Guru Terhadap Mutu Pendidikan di Gugus Rama 2 UPT DISDIKPORA Kecamatan Kembang Kabupaten Jepara. PPs Manajemen Pendidikan IKIP PGRI Semarang.

Siswanto. 2006. Pengantar Manajemen. Jakarta: Bumi Aksara.

Sugiyono. 2012. Metode Penelitian Kuantitatif, Kualitatif dan $R \& D$. Bandung: Alfabeta

Sujanto, Bedjo. 2009. Manajemen Pendidikan Berbasis Sekolah: Model Pengelolaan Sekolah di Era Otonomi Daerah. Jakarta: Sagung Seto.

Sukmadinata, Nana Syaodih. 2011. Metode Penelitian Pendidikan. Bandung: PT Remaja Rosdakarya

Sutarto. 1998. Dasar-Dasar Kepemimpinan Administrasi. Yogyakarta: Gajah Mada University Press.

Suyono. 2009. Pembelajaran Efektifdan ProduktifBerbasis Literasi:Analisis Konteks, Prinsip, dan Wujud Alternatif Strategi Implementasinya di Sekolah. Universitas Negeri Malang: Sastra Indonesia Fak. Sastra

Wahjosumidjo. 2005. Kepemimpinan Kepala Sekolah. Jakarta: PT Raja Garfindo Persada.

Yukl, Gary A. 1989. Leadership in Organization. Prentice Hall International Inc. 